\title{
ENGEVISTA
}

Página da revista: http://www.uff.br/engevista/seer/

\section{Selective flotation of sulphides from a gold mining operation}

\author{
Diego Macedo Veneu ${ }^{1}$ \\ Thais Ferreira Marks Brasil Duque ${ }^{2}$ \\ Getúlio Gomes Oliveira Júnior ${ }^{3}$ \\ Rodrigo Barsante Gomides ${ }^{4}$ \\ Claudio Luiz Schneider 5 \\ Marisa Bezerra de Mello Monte ${ }^{6}$
}

Resumo: Neste trabalho apresenta-se um estudo para obtenção de sulfetos como subprodutos do concentrado mais limpo de ouro gerado a partir do processo de flotação do minério aurífero sulfetado da mina Morro do Ouro. A análise química do concentrado de ouro apresentou um teor de aproximadamente 22,05\% S, na forma de um concentrado de sulfetos. A liberação dos sulfetos foi analisada por meio de MEV com mineralogia automatizada de segunda geração (MLA). Para a etapa de recuperação de calcopirita, a fração de partículas liberadas de ganga atinge valores acima de $90 \%$, para a de galena acima de $92 \%$ e para a de esfalerita acima de $96 \%$, em todas as frações. Por outro lado, a fração de partículas liberadas dos minerais de interesse é menor que 0,52\% para a etapa de recuperação de calcopirita, 0,65\% para a de galena e $0,28 \%$ para a de esfalerita, em todas as frações, refletindo os baixos teores destes minerais. O emprego dos coletores Promoter A, B e C permitiu uma maior seletividade do circuito de flotação apresentado. As recuperações de calcopirita, galena e esfalerita nas etapas Rougher foram de $82 \%, 73 \%$ e $62 \%$, respectivamente.

Palavras-chave: Flotação, minerais sulfetados, liberação, coletores.

\footnotetext{
${ }^{1}$ UFRJ - Universidade Federal do Rio de Janeiro

${ }^{2}$ UFRJ - Universidade Federal do Rio de Janeiro

${ }^{3}$ Kinross Gold Corporation

${ }^{4}$ Kinross Gold Corporation

${ }^{5}$ CETEM - Centro de Tecnologia Mineral

${ }^{6}$ Instituto Tecnológico Vale
} 
ISSN: $1415-7314$

ISSN online: $2317-6717$

Abstract: This paper presents a study to obtain sulphide as byproducts of a concentrated cleaner of gold generated from the flotation process of sulphide gold ore of mine Morro do Ouro. Chemical analysis of the concentrated of gold showed a content of approximately $22.05 \% \mathrm{~S}$, in the form of a bulk sulphides. The liberation of the sulphides was measured using a SEM with second generation automated mineralogy $(M L A)$. For the chalcopyrite recovery step, the fraction of liberated gangue particles is above $90 \%$, for galena up to $92 \%$ and sphalerite above $96 \%$, in all sizes. Moreover, the fractions of particles of minerals of interest that are completely liberated are below $0.52 \%$ for the chalcopyrite recovery step, $0.65 \%$ for galena and $0.28 \%$ for sphalerite, in all sizes. The use of collectors Promoter A, $\mathrm{B}$, and $\mathrm{C}$ allowed greater selectivity in the flotation circuit presented. The recoveries of chalcopyrite, galena and sphalerite in the Rougher steps were $82 \%, 73 \%$ and $62 \%$, respectively.

Keywords: Flotation, sulphide minerals, liberation, collectors. 


\section{Introduction}

Activities related to the production of minerals generate a significant volume of mineral mass that is rejected in the mining and beneficiation processes (Soares, 2010). The tailings from ore processing units contain a large quantity of solid particles in suspension, heavy metal ions, flotation reagents, organic matter etc (Chen et al., 2009).

The tailings from the industrial flotation circuit in plant 2 of a gold mining company are discharged into the tailings dam at a rate of $41 \mathrm{Mt} / \mathrm{year}$. Studies are being conducted on desulphurizing the tailings and producing differentiated sulphide concentrates from B-2 ore containing $3 \%$ to $5 \%$ sulphides distributed along the rock foliation and concentrated in quartz boudins. The aim of previous studies was to recover by-products and reuse the tailings generated by the process with a view to reducing the size of tailings disposal areas. The aim of this study was to evaluate the performance of reagent systems for the selective flotation of sulphides (chalcopyrite, sphalerite and galena) from gold flotation concentrate collected in the new plant at company, because these samples have higher amounts of sulphides, optimizing the results of the study.

Flotation is an industrial process for selectively separating valuable minerals from nonvaluable minerals (King, 2001; Wills and Napier-Munn, 2006). The characteristics of the particles to be processed (size, composition, hydrophobicity, hydrodynamic environment) and the chemical characteristics of the solution are decisive factors in good flotation (SandovalZambrano and Montes-Arenas, 2012).

Over the last few years, many studies have been conducted using chelate reagents for sulphide flotation, although xanthates are still commonly used as collectors in flotation processes in the non-ferrous metals beneficiation industry. However, these collectors are active for the entire class of sulphide minerals and not specific to an individual mineral (Maier et al., 1997). Non-traditional collectors (i.e. non-xanthates) are being used in sulphide flotation due to the complex combinations of the majority of exploitable minerals (Gorken et al., 1992; Kant et al., 1994; Uribe-Salas et al., 2000). Non-traditional collectors are chelate reagents whose structure contains donor atoms with a chemical affinity for specific metal ions, conferring high selectivity.

For example, the nitrogen in thiocarbamates suggests a more covalent arrangement than the oxygen in traditional xanthates, but the phosphorus in the dithiophosphinates suggests an even more covalent arrangement in the functional group. According to Lotter and Bradshaw (2010), the differences in the behaviours of the collectors are attributable to the differences in the structure and consequent behaviour of the donor atom.

By the way, oxygen has a single electron pair with more highly polarized atoms, and tends to be an electron donor, whereas nitrogen tends to be an electron acceptor. Therefore, the 
oxygen atom in the dithiophosphinate molecule has a strong electron-stripping effect. This, combined with the fact that phosphorus is more electropositive, suggests that dithiophosphinates are more selective collectors. However, an increase in the length of the alkyl chain (propyl to butyl) can reduce the solubility of the metal salt formed, making it stronger. For thiocarbamates, the $\mathrm{N}$ is less electronegative than the $\mathrm{O}$, which has a greater tendency to donate electrons, resulting in a less selective, although stronger, collector.

\section{Materials and methods \\ 2.1. Samples and Reagents}

Samples of gold cleaner concentrate (approx. $150 \mathrm{~kg}$ ) were collected in the flotation circuit in plant 2 of a gold mining company and stored in a nitrogen atmosphere. The samples received were homogenized and subdivided into subsamples of approximately $1 \mathrm{~kg}$, for use in the analysis and liberation studies and the flotation studies. Chemical analysis of the gold concentrates showed that the typical average feed composition is $7.2 \mathrm{~g} / \mathrm{t} \mathrm{Au}, 22.05 \% \mathrm{~S}, 6147 \mathrm{~g} / \mathrm{t}$ As, $15.2 \% \mathrm{Fe}, 1392 \mathrm{~g} / \mathrm{t} \mathrm{Cu}, 1715 \mathrm{~g} / \mathrm{t} \mathrm{Zn}$ and $3382 \mathrm{~g} / \mathrm{t} \mathrm{Pb}$. The $\mathrm{P}_{80}$ for the cleaner concentrate was approximately $38 \mu \mathrm{m}$. The collectors evaluated were: Promoter A, B and C. Table 1 gives the average composition of the collectors evaluated. These collectors were tested to choose the better collector for the flotation circuit proposed. The frother used was a blend of aliphatic alcohols. In the sphalerite flotation stage, $\mathrm{CuSO}_{4}$ 97\% P.A. was used as an activator.

Table 1: Average composition of collectors

\begin{tabular}{lll}
\hline \multicolumn{1}{c}{ Reagents } \\
\hline Collector & Composition & $\mathbf{\%}(\mathbf{w} / \mathbf{w})$ \\
\hline \multirow{2}{*}{ Promoter A } & Thionocarbamate & $60-100$ \\
& Isobutanol & $5-7.5$ \\
& Butanol & $5-7.5$ \\
\hline \multirow{2}{*}{ Promoter B } & Sodium Di-isobutyl dithiophosphinate & $50-52$ \\
& Triisobutylphosphinate & 1.0 \\
\hline \multirow{2}{*}{ Promoter C } & Isopropyl ethyl thionocarbamate & $88-94$ \\
& Isopropanol & $2-5$ \\
\hline
\end{tabular}

\subsection{Sample Preparation and SEM/MLA Image Acquisition and Processing}

The sample examined was therefore subjected to mineralogical characterization tests and liberation studies, carried out by scanning electron microscopy (SEM) with a second generation automated mineralogy system (MLA-Mineral Liberation Analyzer). The new microscope can be used for rapidly identifying and discriminating the mineral phases from backscattered electron images combined with EDS images (Energy-dispersive X-ray spectroscopy). The automated system produces relevant information on associations among the various mineral phases, and on liberation and particle size band. 
For the characterization by MLA, $700 \mathrm{~g}$ of the sample was classified by wet sieving to obtain the various size fractions and determine the content levels for each size band. Amounts of approximately $5 \mathrm{~g}$ were obtained from the various fractions after homogenization and taken for producing the specimens. The specimens were prepared by adding approximately $12 \mathrm{~g}$ epoxy resin for each $5 \mathrm{~g}$ sample in a mould $30 \mathrm{~mm}$ in diameter, where it remained for 3 days (drying time). After drying, specimen surfaces were polished using Struers Tegra equipment and $75 \mu \mathrm{m}$, $15 \mu \mathrm{m}, 9 \mu \mathrm{m}$ and $6 \mu \mathrm{m}$ abrasives, and the final finish was obtained using suspensions of $3 \mu \mathrm{m}$ and $1 \mu \mathrm{m}$ diamond to produce random slice surfaces. The polished specimens were then coated with carbon to produce images using the scanning electron microscope coupled to the $\mathrm{x}$-ray dispersive energy system (SEM/EDS - FEI Quanta 400). The studies were conducted using the MLA system with MLA Suite 2008 software.

Liberation analysis was conducted by counting particles and examining their respective compositions in terms of the mass of minerals of interest, chalcopyrite, galena and sphalerite, in respect of liberation classes of $0 \%$ (gangue minerals), $0 \%$ to $100 \%$ (minerals of interest as a proportion of other minerals) and finally $100 \%$ particles (minerals of interest $100 \%$ liberated) in the various fractions.

\subsection{Flotation Tests}

The flotation tests were run in a sub-aerated D12 Denver laboratory flotation cell at $1500 \mathrm{rpm}$, on approximately $1 \mathrm{~kg}$ pulp with a concentration of solids between $30 \%$ and $40 \%$. The $\mathrm{pH}$ was controlled using sodium hydroxide solutions (10\%). First, the pulp was homogenized and adjusted to the required $\mathrm{pH}$ value. After adding the collector (conditioning time $=1$ min.) and the frother, air was introduced into the cell and the time for each Rougher step flotation was $5 \mathrm{~min}$.

The flotation process selected was aimed at selectively recovering first $\mathrm{Cu}$, then $\mathrm{Pb}$ and finally $\mathrm{Zn}$, for this, the collectors were tested separately in each flotation step to obtain the best sequence of addition of the collectors to the proposed circuit.

The tests were run in triplicate. The electrochemical potential (Eh) of the pulp was measured at all stages in the flotation tests (initial pulp Eh and Eh during the conditioning and flotation stages) using a saturated calomel electrode (SCE) and platinum indicator electrode. The flotation tests were run as shown in the flowchart in Figure 1.

The $\mathrm{pH}$ for the Rougher steps of $\mathrm{Cu}$ and $\mathrm{Pb}$ was 9.8 and the test conditions as follows: collector conditioning time of $1 \mathrm{~min}$, collector concentration of $20 \mathrm{~g} / \mathrm{t}$, flotation time of 5 minutes and $10 \mathrm{~g} / \mathrm{t}$ of frother. The $\mathrm{pH}$ for the Rougher step of $\mathrm{Zn}$ was 12. The process involved initial conditioning $(2 \mathrm{~min})$ with the $\mathrm{CuSO}_{4}$ activator at a concentration of $200 \mathrm{~g} / \mathrm{t}$, a second 
conditioning phase with the collectors $(1 \mathrm{~min})$ at a concentration of $20 \mathrm{~g} / \mathrm{t}$ and finally, flotation time of $5 \mathrm{~min}$, using $10 \mathrm{~g} / \mathrm{t}$ of frother.

All the products obtained (tailings and Rougher concentrates) were dry-filtered at $60^{\circ} \mathrm{C}$ and weighed for calculating the recovered mass. Portions of these products were sent to company laboratories for chemical analysis of $\mathrm{Au}, \mathrm{As}, \mathrm{Pb}, \mathrm{Zn}, \mathrm{Cu}, \mathrm{Fe}$ and $\mathrm{S}$. The analytical data were used for calculating the metallurgical balance sheet.

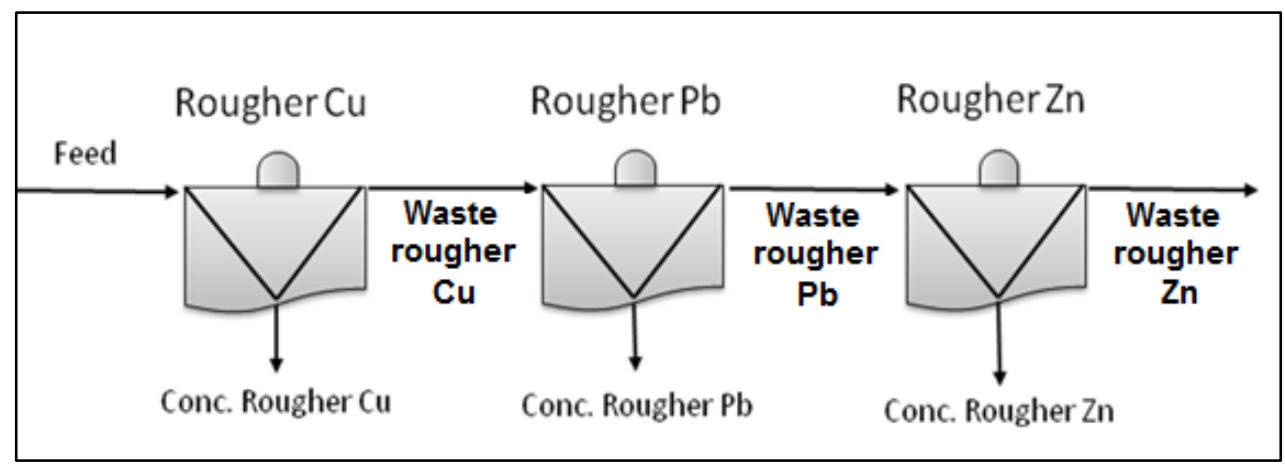

Figure 1: Flotation test circuit.

\section{Results and discussion}

\subsection{Mineral Liberation Studies}

Through the characterization of the sample and metallurgical balance it is concluded that the $\mathrm{Cu}, \mathrm{Zn}$ and $\mathrm{Pb}$ present in the sample are exclusively associated to chalcopyrite, galena and sphalerite, respectively.

Figure 2 shows mineral liberation as a function of mass percentage, per grade class evaluated. In Figure 2A, 2B and 2C the y-axis is arbitrarily cut into $8 \%$ for better visualization of the composites and liberated chalcopyrite, galena and sphalerite particles, respectively. We can see clearly from Figure 2 that the $0 \%$ liberation class, i.e., gangue minerals, corresponds to the highest percentages in the composition of particles expressed in terms of mass, by comparison with all minerals of interest. For the chalcopirite recovery step, the liberation of gangue minerals reaches values above $90 \%$, for galena up to $92 \%$ and sphalerite above $96 \%$, in all fractions. In contrast, for $100 \%$ liberated minerals of interest, the values are below $0.52 \%$ for the chalcopyrite recovery step, $0.65 \%$ for galena and $0.28 \%$ for sphalerite, in all size fractions. These results represent extremely low contents of these minerals of interest (approximately $0.4 \%$ for chalcopyrite, $0.35 \%$ for galena and $0.22 \%$ for sphalerite) by comparison with other minerals. 


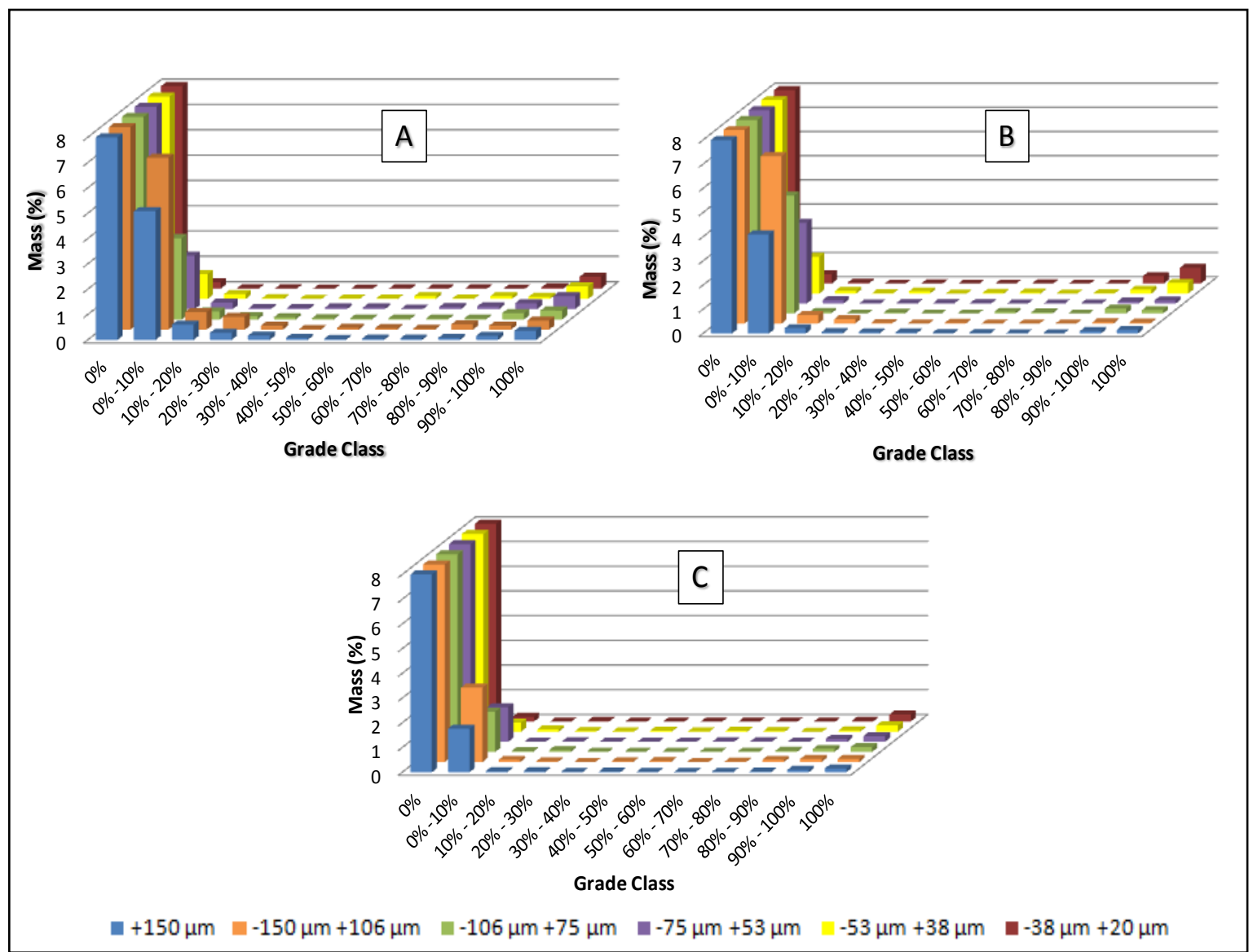

Figure 2: Distribution of particle grades, conditional by particle size. (A) $\mathrm{Cu}$; (B) $\mathrm{Pb}$; (C) $\mathrm{Zn}$.

Based on the results of distribution of the contents by mass of the particles in the different fractions shown in Figure 2, was calculated release of minerals of interest. In Figure 3 we can observe a similar behavior for the three minerals, i.e., the fraction $-38+20 \mu \mathrm{m}$ has the highest values corresponding to $84.6 \%$ for chalcopyrite, $66 \%$ for galena and $88.6 \%$ for sphalerite, with the increase of the size particles, the liberation grade decreased for all evaluated minerals.

According to Olubambi et al. (2009), the efficiency of practically all mineral processing and hydrometallurgical operations is a function of the size of the particles processed, due to the relatively high costs of particle size reduction and the problems associated with the liberation of the minerals. This means that liberation is definitively an important issue. Data from the mineralogical association show that it is in these size fractions that the minerals of interest (chalcopyrite, galena and sphalerite) are associated with gangue minerals. Within these percentages of associated minerals, the main gangue mineral is pyrite, with figures of $55 \%$ for chalcopyrite, $79 \%$ for galena and $68 \%$ for sphalerite. Figure 4 shows a synthesis of the results obtained for theoretical recoveries and grades of the minerals of interest corresponding to chalcopyrite, galena and sphalerite in the concentrate obtained from the industrial flotation circuit, combining the different fractions. 


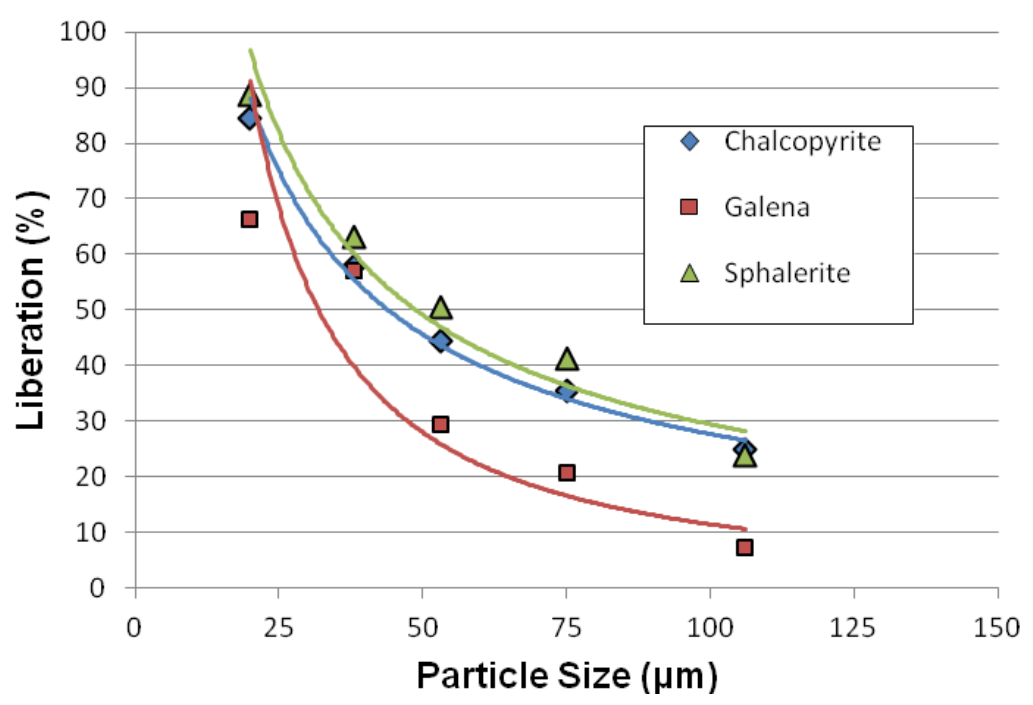

Figure 3: Liberation of particles, conditional on particle size.

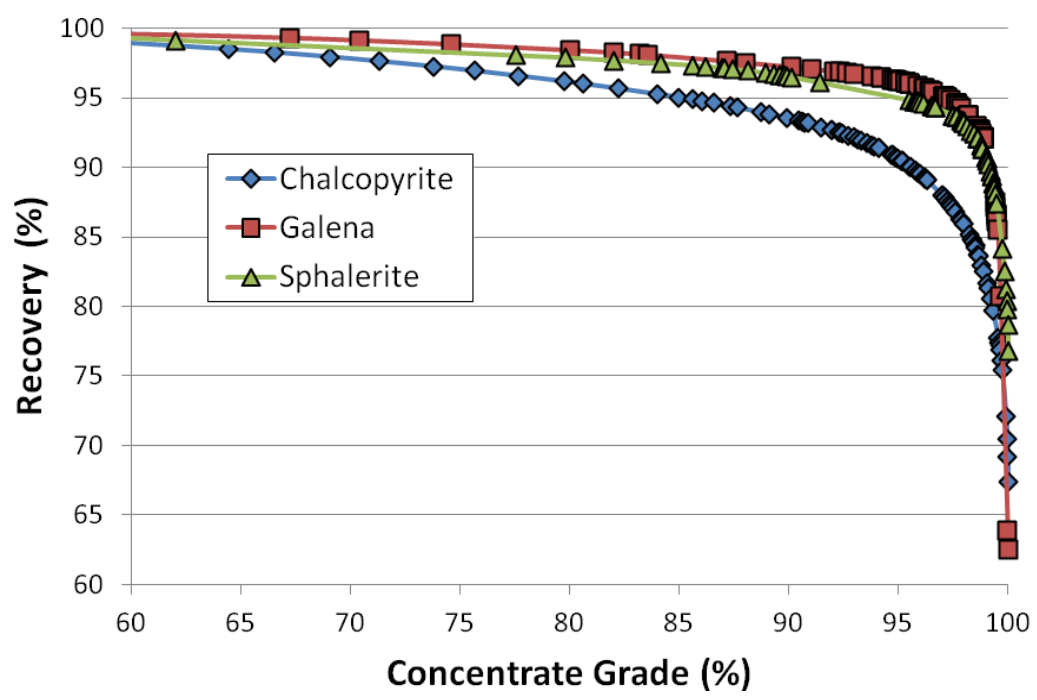

Figure 4: Theoretical recoveries of chalcopyrite, galena and sphalerite when combining the several size fractions.

\subsection{Flotation Tests}

Figure 5 gives the recoveries of the three minerals of interest and the main gangue minerals, pyrite $\left(\mathrm{FeS}_{2}\right)$ and arsenopyrite (FeAsS), for the Promoter C, B and A collectors tested in the chalcopyrite rougher cell with the objective of identifying possible collector selectivity for minerals of interest.

It shows that Promoter B exhibited, on average, the highest recovery figures for chalcopyrite and galena (88.7\% and $77.4 \%$, respectively) and the lowest for sphalerite (20\%). However, it recovered more pyrite $(43.2 \%)$ than the other collectors tested. Pecina-Treviño et al. (2003) observed a similar phenomenon in their microflotation tests. Using the same collector, they obtained high recovery figures for galena, but also high recovery figures for pyrite, suggesting that the pyrite surface was being activated by species of lead that appeared in 
solution as a result of the dissolution of $\mathrm{Pb}$ sites on the surface of the galena. These species, once adsorbed on the pyrite surface, produce an effect similar to that of the galena, promoting collector adsorption.

The results of the tests conducted on the Promoter $\mathrm{C}$ collector show a more uniform recovery for both chalcopyrite and galena (58.5\% and 57.9\%, respectively), and the highest for sphalerite $(32.6 \%)$. Of the collectors tested, Promoter C produced low recovery figures for pyrite and arsenopyrite (11.5\% and 17.7\%, respectively). On the other hand, Aero 3894, which is a thiocarbamate with a longer alkyl chain, exhibited chalcopyrite recovery of $73 \%$, higher than Promoter C. Recoveries of other minerals of interest, as well as gangue minerals, were close to those obtained using Promoter C, corresponding to approximately 51\% for galena, $28 \%$ for sphalerite, $16.8 \%$ for pyrite and $18 \%$ for arsenopyrite.

Based on the results above, we opted for the circuit in Figure 1 with addition of the Promoter A collector in the chalcopyrite rougher cell, the Promoter B collector for the galena rougher cell, adding the Promoter A collector once again in the sphalerite rougher cell, since the sphalerite has already been activated with copper sulphate.

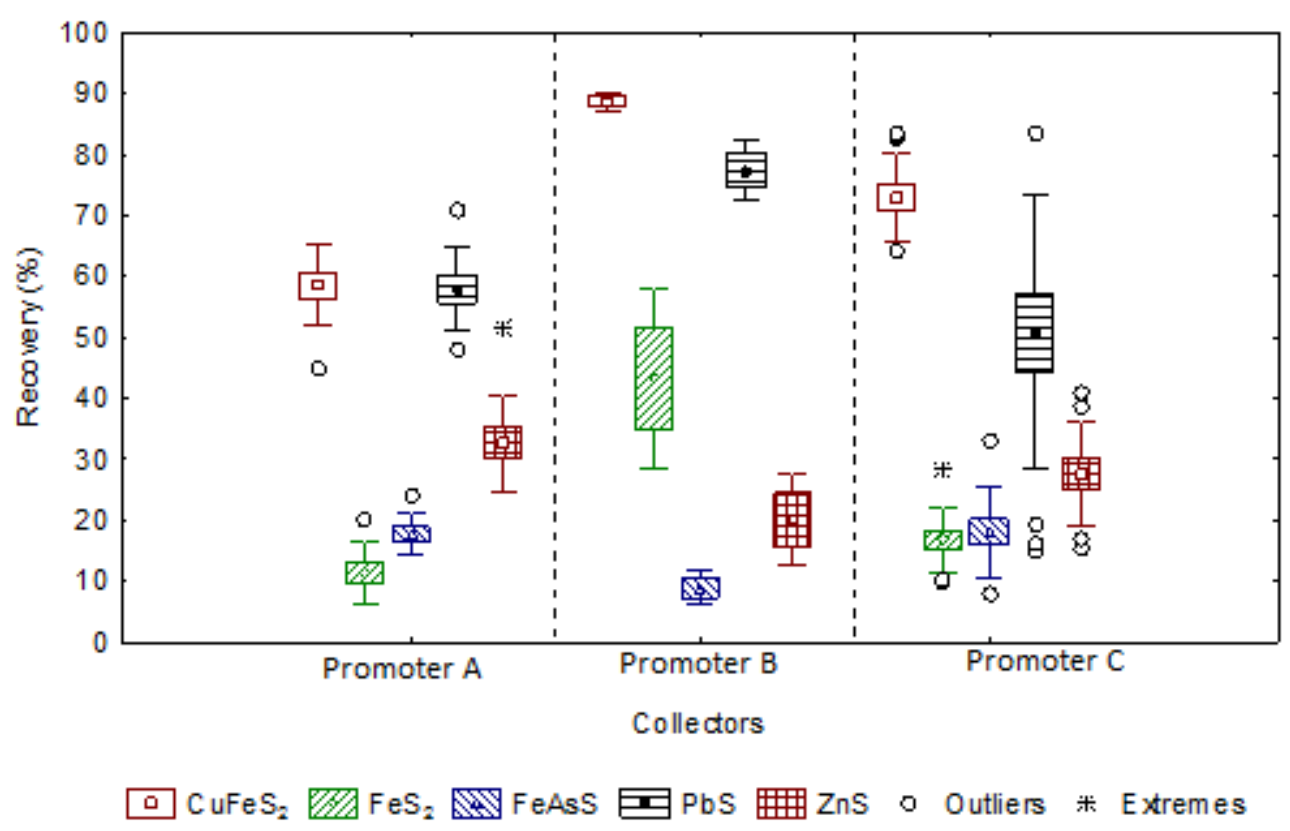

Figure 5: Recovery of minerals of interest and the main gangue minerals (pyrite and arsenopyrite).

\subsection{Flotation Circuit Tests}

Figure 6 illustrates a test conducted in triplicate, representing recoveries of minerals of interest $\left(\mathrm{CuFeS}_{2}, \mathrm{PbS}\right.$ and $\left.\mathrm{ZnS}\right)$ and the main gangue minerals $\left(\mathrm{FeS}_{2}\right.$ and $\left.\mathrm{FeAsS}\right)$ in the $\mathrm{Cu}, \mathrm{Pb}$ and Zn Rougher cells.

As can be seen in Figure 6, the use of Promoter A and B collectors in the sequences described above resulted in some selective recovery of chalcopyrite, galena and sphalerite in the 
three rougher flotation cells. In the $\mathrm{Cu}$ rougher cell, the average content and recovery were of $1192 \mathrm{~g} / \mathrm{t}$ and $82 \%$ for chalcopyrite, respectively. Already for galena, sphalerite and pyrite the recoveries were lower than $19 \%$, while for arsenopyrite was lower than $10 \%$.

In the $\mathrm{Pb}$ rougher cell, the average content and recovery of galena were of $2245 \mathrm{~g} / \mathrm{t}$ and about $73 \%$. The sphalerite recovery was lower than $19 \%$ while for chalcopyrite and arsenopyrite were obtained recoveries about $11 \%$. However, the highest recoveries were for pyrite in all three stages, corresponding to $30 \%$. According to Pecina-Treviño et al. (2003), this collector shows a pronounced affinity toward lead species, either in the galena lattice or adsorbed on the pyrite surface as lead-hydrolyzed species. The same author concludes that the use of this collector in the flotation of galena-pyrite slurries does not eliminate the possibility of having the pyrite activated with lead species.

The concentration of $20 \mathrm{~g} / \mathrm{t}$ of the collectors used could have affected recovery of both minerals of interest and the gangue minerals. According to Johnson (2006) in his studies on the liberation of sulphide minerals, the addition of the collector should be restricted to avoid undesired recovery of gangue minerals in intermediate fractions. However, recovery of minerals of interest liberated in fine fractions can drop in some systems, as a result of insufficient adsorption of the collector per unit area and/or excessive collection of activated species such as ferrous hydroxides.

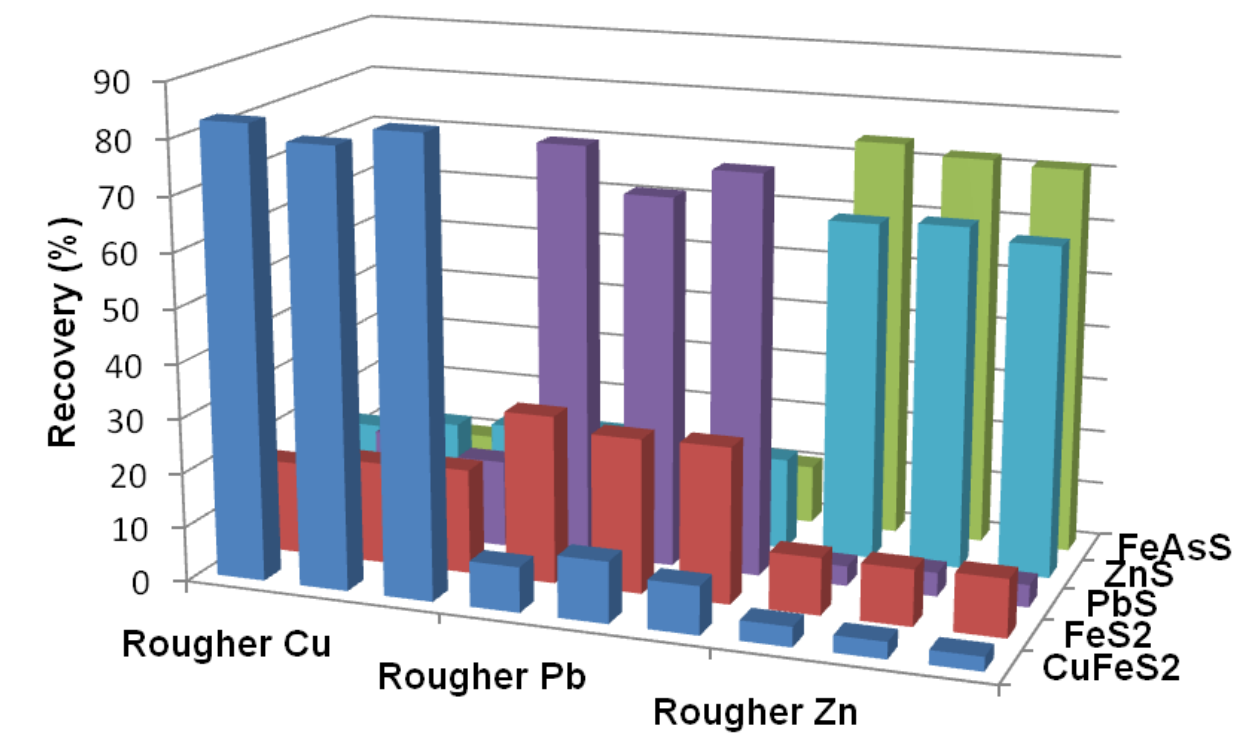

Figure 6: Recoveries of chalcopyrite, galena, sphalerite, pyrite and arsenopyrite in the rougher flotation cells.

The activation of zinc minerals, especially sphalerite, by copper sulphate is already well known (Finkelstein, 1999). In the $\mathrm{Zn}$ rougher cell with the addition of copper sulphate (200 g/t), there was a concentration of sphalerite that corresponded an average content and recovery of 
$931 \mathrm{~g} / \mathrm{t}$ and $62 \%$, respectively. However, the gangue minerals, pyrite and arsenopyrite, were recovered, on average at $10 \%$ and $71 \%$, respectively. Similar results were obtained by Natarajan and Nirdosh (2006), who used a new collector (HCNPHA) for sphalerite, with recovery of approximately $80 \%$. However, the pyrite was flotated with the sphalerite, a significant disadvantage. Shen et al. (1997), studying the influence of $\mathrm{pH}$ on the selective recovery of sphalerite and pyrite, both oxidized, observed that in a highly alkaline medium (pH 11 to 12), the highest recoveries of sphalerite $(>85 \%)$ were achieved and the lowest of pyrite $(<20 \%)$. Wang et al. (1989) showed that the copper adsorption rate resulting from activation is much faster for sphalerite than pyrite. In contrast to pyrite, arsenopyrite seems to be activated together with sphalerite, resulting in high arsenopyrite recoveries in a strongly alkaline medium.

\section{Conclusions}

The study of the liberation of sulphides using scanning electron microscopy with second generation automated mineralogy system (MLA-Mineral Liberation Analyzer) revealed that the liberation of gangue minerals in all fractions was as follows: chalcopyrite higher than $90 \%$, galena higher than $92 \%$ and sphalerite higher than $96 \%$. In contrast, the percentages of completely liberated particles are small fractions, lower than $0.52 \%$ for chalcopyrite, $0.65 \%$ for galena and $0.28 \%$ for sphalerite, in all sizes, showing how low the contents were in the concentrates, by comparison with pyrite and arsenopyrite. The use of Promoter A and B collectors allowed some selectivity in the recovery of chalcopyrite, galena and sphalerite in the three rougher flotation cells. In the $\mathrm{Cu}$ rougher cell, the average content and recovery were of $1192 \mathrm{~g} / \mathrm{t}$ and $82 \%$ for chalcopyrite, respectively. In the $\mathrm{Pb}$ rougher cell, the average content and recovery of galena were of $2245 \mathrm{~g} / \mathrm{t}$ and about $73 \%$. In the $\mathrm{Zn}$ rougher cell, the average content and recovery were of $931 \mathrm{~g} / \mathrm{t}$ and $62 \%$.

\section{References}

SOARES, L. 2010. Barragem de Rejeitos. In: LUZ, A.B. et al. (Eds). Tratamento de Minérios. 5 ed. Rio de Janeiro, RJ, Brasil: Centro de Tecnologia Mineral, p.831-888.

CHEN, J.M.; LIU, R.Q.; SUN, W.; QIU, G.Z. 2009. Effect of mineral processing wastewater on flotation of sulfide minerals, Transactions of Nonferrous Metals Society of China, v.19, p. 454457.

KING, R.P. 2001. Modelling and Simulation of Mineral Processing Systems. ButterworthHeinemann, Oxford, p. 289.

WILLS, B.A., NAPIER-MUNN, T.J. 2006. Wills' Mineral Processing Technology: An Introduction to the Practical Aspects of Ore Treatment and Mineral Recovery. Seventh ed., Elsevier, Great Britain, p. 71-75.

SANDOVAL-ZAMBRANO, G.; MONTES-ATENAS, G. 2012. Errors in the estimation of size-by-liberation flotation rate constants, Minerals Engineering, v. 27-28, p. 1-10.

MAIER, G.S.; QIU, X.; DOBIAS, B. 1997. New collectors in the flotation of sulphide minerals: a study of the electrokinetic, calorimetric and flotation properties of sphalerite, galena and 
chalcocite, Colloids and Surfaces A: Physicochemical and Engineering Aspects, v. 122, p. 207225.

GORKEN, A., NAGARAJ, D.R., RICCIO, P. 1992. The role of pulp redox potential and modifiers in complex sulfide flotation with DTPI. In: Woods, R., Richardson, R. (Eds.), Proc. Int. Symp. Electrochemical Miner. Met. Process, III. Electrochemical Society, Pennington, N.J., p. $92-117$.

KANT, C., RAO, R., FINCH, J. 1994. Distribution of surface metal ions among the products of copper flotation. Minerals Engineering, v. 7, p. 905-916.

URIBE-SALAS, A., MARTINEZ-CAVAZOS, T.E., NAVA-ALONSO, F.C., MÉNDEZNONELL, J., LARA-VALENZUELA, C. 2000. Metallurgical improvement of a lead/copper flotation stage by pulp potential control. Int. J. Miner. Process. V. 59, p. 69-83.

LOTTER, N.O.; BRADSHAW, D.J. 2010. The formulation and use of mixed collectors in sulphide flotation, Minerals Engineering, v. 23, p. 945-951.

AL-WAKEEL, M.I.; LIN, C.L.; MILLER, J.D. 2009. Significance of liberation characteristics in the fatty acid flotation of Florida phosphate rock, Minerals Engineering, v. 22, p. 244-253.

OLUBAMBI, P.A.; POTGIETER, J.H.; NDLOVU, S.; BORODE, J.O. 2009. Electrochemical studies on interplay of mineralogical variation and particle size on bioleaching low grade complex sulphide ores, Transactions of Nonferrous Metals Society of China, v. 19, p. 13121325.

PECINA-TREVIÑO, E.T.; URIBE-SALAS, A.; NAVA-ALONSO, F; PÉREZ-GARIBAY, R. 2003. On the sodium-diisobutyl dithiophosphinate (Aerophine 3418A) interaction with activated and unactivated galena and pyrite, International Journal of Mineral Processing, v. 71, p. 201- 217.

JOHNSON, N.W. 2006. Liberated 0-10 $\mathrm{lm}$ particles from sulphide ores, their production and separation-Recent developments and future needs, Minerals Engineering, v. 19, p. 666-674.

FINKELSTEIN, N.P. 1999. Addendum to: the activation of sulfide minerals for flotation: a review, International Journal Mineral Processing, v. 55, p. 283-286.

NATARAJAN, R.; NIRDOSH, I. 2006. New collectors for sphalerite flotation, International Journal Mineral Processing, v. 79, p. 141-148.

SHEN, W.Z.; FORNASIERO, D.; RALSTON, J. 1997. Effect of collectors conditioning pH and gases in the separation of sphalerite from pyrite, v. 11, p. 145-158.

WANG, X.H.; FORSSBERG, E.; BOLIN, N.J. 1989. Adsorption of Copper(II) by pyrite in acidic to neutral pH media, Scandinavian Journal of Metallurgy, v.18, p. 262-270. 